\title{
CREATION OF THE RATING OF STOCK MARKET ANALYTICAL SYSTEMS ON THE BASE OF EXPERT QUALITATIVE ESTIMATIONS
}

\author{
Olga A. Siniavskaya, Boris A. Zhelezko, Roman V. Karpovich* \\ Belorussian State Economic University 220672 Republic of Belarus, Minsk, Partisan Ave. 26 \\ o.siniavskaya@sam-solutions.net,BorisZh@yandex.ru,ramonak@ya.ru
}

\begin{abstract}
In this article the algorithms of creation of the rating of stock market analytical automated systems are proposed. They are based on Zahedi's analytic hierarchy process modification in which triangular fuzzy numbers are used to transform qualitative expert estimations into quantitative ones. An example of practical using of these algorithms is considered.
\end{abstract}

Keywords: Portfolio Investments, Fuzzy Analytical Network Process (FANP), Fuzzy Multiple Criteria Decision Making (FMCDM), Investment Project, Fuzzy Set Theory

\section{Introduction}

Analytic hierarchy process (AHP) devised by Thomas Saaty [3] became one of the wide-spread multi-criteria methods of the best alternative choice. There are many modifications of Saaty's AHP method. One of them was made by Fatemah Zahedi in her work [4] and adopted for quantitative evaluation of expert systems. However, the principle of superiority evaluation, proposed in that work, entails the essential difficulties for expression of the expert opinions if estimation criteria have a qualitative nature. The objective of this article is working out of the algorithms of creation of the rating of stock market analytical systems on the base of Zahedi's method modification, in which qualitative expert opinions about alternatives would be employed during the calculation of generalized quantitative scores of alternatives. This work is the continuation of authors' investigation concerning the AHP improvement $[1,5]$ and the estimation of decision support systems quality [6].

\section{AHP method suggested by F. Zahedi}

F. Zahedi proposes the following simplified algorithm for comparative evaluation of expert systems (ES) [4].

Stage 1. The functional structure of expert systems is defined in the form of evaluation criteria hierarchical tree.

Stage 2. Relative significances (weights) of criteria are defined on each hierarchy level. The sum of all criteria weights must be equal one in each criteria group on hierarchy levels. Then global significances of the lowest level criteria (hierarchical tree leaves) are calculated by the following formula:

$$
w_{k}^{G}=\prod_{v=1}^{H_{k}-1} w_{v}^{L} \cdot w_{k}^{L}
$$

where $w_{k}^{G}$ - global significance of $k$-th criterion which is a leaf of the hierarchical criteria tree; $v$ - numbers of hierarchy levels; $H_{k}$ - amount of hierarchy levels in the branch, which includes $k$-th criterion; $w_{v}^{L}-$ local significances of parent criteria of branch, which includes $k$-th criterion on $H_{k}$-th hierarchy level; $w_{k}^{L}-$ local significance (weight) of $k$-th criterion which is a leaf of the hierarchical criteria tree.

Stage 3. Comparison of alternatives superiority is conducted on criteria, which are the leaves of the hierarchical criteria tree. Relative superiority of one alternative by another one is expressed within the $[0,100]$ interval. We shall mark superiority of $i$-th ES above $j$-th ES on $k$-th criterion as $e_{i j k}$. If there is no superiority, then $e_{i j k}=e_{j i k}=0$, otherwise $e_{j i k}=-e_{i j k}$. Comparison matrices have the following form (table 1). 
Table 1. Matrix for alternatives comparison according to Zahedi's AHP-method

\begin{tabular}{|c|c|c|c|c|}
\hline Criterion $k$ & ES 1 & ES 2 & $\ldots$ & ES N \\
\hline ES 1 & 0 & $e_{12 k}, c_{12 k}$ & $\ldots$ & $e_{1 N k}, c_{1 N k}$ \\
\hline ES 2 & $-e_{12 k}, c_{12 k}$ & 0 & $\ldots$ & $e_{2 N k}, c_{2 N k}$ \\
\hline$\ldots$ & $\ldots$ & $\ldots$ & 0 & $\ldots$ \\
\hline ES N & $-e_{1 N k}, c_{1 N k}$ & $-e_{2 N k}, c_{2 N k}$ & $\ldots$ & 0 \\
\hline
\end{tabular}

In order to reduce uncertainty in expert answers Zahedi proposes alongside with the significance estimation $e_{i j k}$ to indicate a coefficient of confidence in this estimation $c_{i j k} \in(0,1]$. If $c_{i j k}=1$, it means that expert confidence in the estimation $e_{i j k}$ is equal to $100 \%$. Definitive superiority estimation on each criterion is calculated as $e_{i j k} \cdot c_{i j k}$.

Stage 4. Aggregate score of $i$-th alternative is calculated as follows:

$$
Z_{i}=\sum_{k=1}^{m}\left(w_{k}^{G} \sum_{j=1}^{n} c_{i j k} \cdot e_{i j k}\right)
$$

where $m$ - amount of evaluation criteria, which are the leaves of the hierarchical criteria tree; $n$ - amount of alternatives.

Stage 5. Rating of alternatives is created by sorting them on decreasing of their aggregate scores $Z_{i}$. Alternative with the maximal $Z_{i}$ score is recognized as the best alternative.

The main shortcoming of Zahedi's method is necessity of expression of expert opinion about alternatives superiority through the quantitative scale from 0 to 100 . For instance, intermediate estimation of superiority may be equal to $30,35,37,40$ points, and it is difficult for expert to discern these values, especially if the evaluating software is complex and estimation criteria are qualitative (possibilities of graphical interpretation of some financial indices, quality of programming editor, etc). But such difference in quantitative estimation may lead to incorrect result.

\section{Using of qualitative estimations and fuzzy numbers for representation of experts' opinions}

The most convenience form of representation of experts' opinions about alternatives superiority could be the verbal scale, such as «very high superiority, high superiority, average superiority, etc». However, verbal assessment of superiority has two shortcomings. Firstly, probability of unconformity of the matrix with quantitative superiority estimations generated from the matrix with qualitative superiority estimation is not excluded. Secondly, if a number of alternatives is large then estimation of their relative superiority in qualitative form would be difficult and lengthy.

In order to eliminate these shortcomings we propose to estimate not relative superiority of alternatives, but alternatives quality $\left(x_{i k}\right)$ on defined criteria by means of the verbal scale. In table 2 and on figure 1 an example of possible scale of verbal estimations correspondence to quantitative estimations within $[0,100]$ interval is represented.

Table 2. An example of qualitative and quantitative estimations correspondence

\begin{tabular}{|c|c|}
\hline Qualitative (verbal) estimation & $\begin{array}{l}\text { Quantitative (fuzzy interval) estimation } \\
\text { in }\left[a_{1}, a_{2}, a_{3}\right] \text { form } \\
\end{array}$ \\
\hline Absence (ABS) & {$[0,0,10]$} \\
\hline Low $(\mathrm{L})$ & {$[0,10,30]$} \\
\hline Below Average (BA) & {$[10,30,50]$} \\
\hline Average (AVG) & {$[30,50,70]$} \\
\hline Above Average (AA) & {$[50,70,90]$} \\
\hline $\operatorname{High}(\mathrm{H})$ & {$[70,90,100]$} \\
\hline Very High (VH) & {$[90,100,100]$} \\
\hline
\end{tabular}




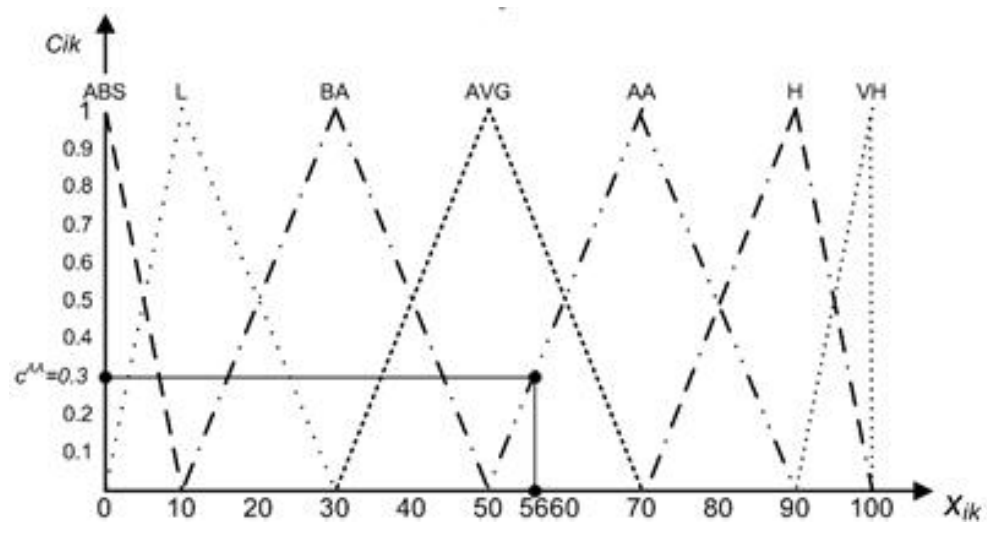

Fig. 1. An example of possible fuzzy interval estimating scale

Quantitative fuzzy interval estimation, which corresponds to verbal formulation, is represented as symmetric or asymmetric fuzzy triangular number $\left[a_{1}, a_{2}, a_{3}\right]$. That means that quality of alternative could be estimated as $a_{2}$ with highest confidence, but if the expert's confidence in his (her) estimation is less than $100 \%$, then quantitative value of estimation may vary within $\left[a_{1}, a_{3}\right]$ interval.

There is also an example of transformation of ambiguous verbal estimation $\left\langle\mathrm{AVG}, \mathrm{c}^{\mathrm{AVG}}=0.7 ; \mathrm{AA}, \mathrm{c}^{\mathrm{AA}}=0.3\right.$ » into quantitative estimation on figure 1 .

Production rules of verbal estimations transformation into quantitative form are represented in table 3.

Table 3. Rules of verbal estimations transformation into quantitative form

\begin{tabular}{|c|c|c|}
\hline Rules & Antecedent (qualitative estimation, $x_{i k}{ }^{\prime}$ ) & Consequent (quantitative estimation, $x_{i k}$ ) \\
\hline \multirow[t]{2}{*}{$\begin{array}{l}\text { Transformation } \\
\text { rule for unambi- } \\
\text { guous estima- } \\
\text { tions }\end{array}$} & $\begin{array}{l}\text { IF expert's confidence in some qualitative } \\
\text { (verbal) estimation is equal } 100 \% \text {, i.e. } \\
c_{i k}=1\end{array}$ & $\begin{array}{l}\text { THEN } x_{i k}=a_{2} \text { for corresponding fuzzy number } \\
\text { from table } 2\end{array}$ \\
\hline & IF $x_{i k}{ }^{\prime}=\left\langle\left\langle\mathrm{H}, \mathrm{c}^{\mathrm{H}}=1 »\right.\right.$ & $\begin{array}{l}\text { mple } \\
\text { THEN } x_{i k}=90\end{array}$ \\
\hline \multirow[t]{2}{*}{$\begin{array}{l}\text { Transformation } \\
\text { rule for ambi- } \\
\text { guous estima- } \\
\text { tions }\end{array}$} & $\begin{array}{l}\text { IF two coefficients of confidence } \mathrm{c}_{i k}{ }^{1} \text { and } \\
\mathrm{c}_{i k}{ }^{2} \text { correspond to two nearby qualitative } \\
\text { (verbal) estimations }\end{array}$ & $\begin{array}{l}\text { THEN } x_{i k}=c \cdot\left(a_{2}-a_{1}\right)+a_{1} \text {, } \\
\text { where } c \text {-coefficient of confidence in higher } \\
\text { verbal estimation; } a_{1}, a_{2}-\text { elements of fuzzy } \\
\text { triangular number, which corresponds to } \\
\text { higher verbal estimation }\end{array}$ \\
\hline & IF $x_{i k}{ }^{\prime}=\left\langle\mathrm{AVG}, \mathrm{c}^{\mathrm{AVG}}=0.7 ; \mathrm{AA}, \mathrm{c}^{\mathrm{AA}}=0.3 » \boldsymbol{E} \boldsymbol{x}\right.$ & $\begin{array}{l}\text { mple } \\
\text { THEN } x_{i k}=0.3 \cdot(70-50)+50=56\end{array}$ \\
\hline
\end{tabular}

Superiority of $i$-th alternative above $j$-th on $k$-th criterion is defined by the following formula [5]:

$$
e_{i j k}=x_{i k}-x_{j k}
$$

Generalized scores of alternatives are calculated as follows:

$$
Z_{i}=\sum_{k=1}^{m}\left(w_{k}^{G} \sum_{j=1}^{n} e_{i j k}\right)
$$

Suggesting algorithms of creation of alternatives rating, based on qualitative expert estimations (Verbal AHP and $\mathrm{Verbal}^{+} \mathrm{AHP}$ ), are compared with Zahedi's algorithm in table 4. Stages 1, 2 and 4 of all this algorithms are executed by experts. The rest stages can be automated. Hereupon AHP algorithm based on qualitative estimations of alternatives quality on criteria, $\left(\mathrm{Verbal}^{+} \mathrm{AHP}\right)$, which doesn't requires the relative comparison of the alternatives, more simply then two another AHP algorithms in spite of the fact that it contains the greater number of stages.

Table 4. Comparison of Zahedi's AHP algorithm with the algorithms based on qualitative experts estimations (Verbal AHP and Verbal $^{+} A H P$ ) 


\begin{tabular}{|c|c|c|}
\hline & $\begin{array}{l}\text { timations of relative superiorities of } \\
\text { alternatives (Verbal AHP) }\end{array}$ & $\begin{array}{l}\text { timations of alternatives quality on } \\
\left.\text { criteria (Verbal }^{+} A H P\right)\end{array}$ \\
\hline \multicolumn{3}{|c|}{ 1. Forming of evaluation criteria hierarchy tree } \\
\hline $\begin{array}{l}\text { 2. Assessment of local criteria } \\
\text { weights by means of Saaty's AHP }\end{array}$ & \multicolumn{2}{|c|}{$\begin{array}{l}\text { 2. Assessment of local criteria weights by means of expert methods in } \\
\text { which there are no relative comparison of criteria pairs (for instance, } \\
\text { Fishburn method) }\end{array}$} \\
\hline \multicolumn{3}{|c|}{ 3. Calculation of global criteria weights by the formula (1) } \\
\hline \multirow[t]{3}{*}{$\begin{array}{l}\text { 4. Evaluation of alternatives rela- } \\
\text { tive superiority in quantitative form } \\
\text { within }[0,100] \text { interval with taking } \\
\text { into account of confidence in esti- } \\
\text { mations }\end{array}$} & $\begin{array}{l}\text { 4. Evaluation of alternatives supe- } \\
\text { riority in qualitative form by means } \\
\text { of scale from table } 2 \text { with taking in- } \\
\text { to account of confidence in estima- } \\
\text { tions }\end{array}$ & $\begin{array}{l}\text { 4. Evaluation of quality of alterna- } \\
\text { tives by means of scale from table } 2 \\
\text { with taking into account of confi- } \\
\text { dence in estimations }\end{array}$ \\
\hline & $\begin{array}{l}\text { 5. Transformation of verbal estima- } \\
\text { tions into quantitative form by } \\
\text { means of rules from table } 3 \text { (with } \\
\text { use of } e_{i j k} \text { ' and } e_{i j k} \text { instead of } x_{i j k} \text { ' and } \\
x_{i j k} \text { ). }\end{array}$ & $\begin{array}{l}\text { 5. Transformation of verbal estima- } \\
\text { tions into quantitative form by } \\
\text { means of rules from table } 3\end{array}$ \\
\hline & & $\begin{array}{l}\text { 6. Calculation of relative superiori- } \\
\text { ties of alternatives as differences } \\
\text { (distances) between their absolute } \\
\text { estimation by the formula (3). }\end{array}$ \\
\hline $\begin{array}{l}\text { 5. Calculation of aggregate scores } \\
\text { of alternatives } Z_{i} \text { by the formula } \\
\text { (2). }\end{array}$ & $\begin{array}{l}\text { 6. Calculation of aggregate scores } \\
\text { of alternatives } Z_{i} \text { by the formula } \\
\text { (4). }\end{array}$ & $\begin{array}{l}\text { 7. Calculation of aggregate scores } \\
\text { of alternatives } Z_{i} \text { by the formula } \\
\text { (4). }\end{array}$ \\
\hline $\begin{array}{l}\text { 6. Creation of the rating of alterna- } \\
\text { tives on decreasing of } Z_{i} \text { value }\end{array}$ & $\begin{array}{l}\text { 7. Creation of the rating of alterna- } \\
\text { tives on decreasing of } Z_{i} \text { value }\end{array}$ & $\begin{array}{l}\text { 8. Creation of the rating of alterna- } \\
\text { tives on decreasing of } Z_{i} \text { value }\end{array}$ \\
\hline
\end{tabular}

\section{Creation of the rating of stock market analytical systems on the base of suggested AHP modifications}

Suggested AHP algorithms may be efficiently used for the evaluation of stock market analytical systems and creation of their rating. We shall consider an example of the practical using of the given AHP algorithms. Evaluating systems are described in table 5, created on the base of the article [2].

Table 5. Description of stock market analytical automated systems

\begin{tabular}{|c|c|}
\hline Stock market analytical automated systems & $\begin{array}{c}\text { Supported methods, functions and } \\
\text { features }\end{array}$ \\
\hline OMEGA Research Trade Station (TS) & $\begin{array}{l}\text { Includes } 150 \text { indicators, } 15 \text { trade systems, } 30 \text { graphical } \\
\text { tools, additional tools ShowMe and PaintBar, built-in } \\
\text { programming language EasyLanguage, programming } \\
\text { editor PowerEditor. Has a possibility to analyze dif- } \\
\text { ferent length trends. }\end{array}$ \\
\hline OMEGA Research Super Charts (SC) & $\begin{array}{l}\text { Includes more than } 80 \text { indicators, } 15 \text { trade systems, } 15 \\
\text { graphical tools, additional tools ShowMe, PaintBar } \\
\text { and Expert Indicator (latter tool for indicators explana- } \\
\text { tion). Has a possibility to analyze only day, week and } \\
\text { month trends. Has no programming editor. }\end{array}$ \\
\hline Reuters Graphics Professional (RGP) & $\begin{array}{l}\text { Includes } 65 \text { indicators, } 6 \text { types of trend lines (up to } 200 \\
\text { lines on the graph), possibilities of new indicators and } \\
\text { return curves creation. Allows showing up to } 16 \\
\text { graphs simultaneously. Has an ability of data exchange } \\
\text { with Microsoft Excel. Supports fundamental analysis. }\end{array}$ \\
\hline DanaLyzer Euro Charts (DEC) & $\begin{array}{l}\text { Includes } 40 \text { indicators. Has a possibility of data repre- } \\
\text { sentation in the form of linear graphs, histograms, } \\
\text { «Japanese candles», etc. Uses different length trends. }\end{array}$ \\
\hline EQUIS MetaStock Professional (MSP) & Includes more than 120 indicators and linear depen- \\
\hline
\end{tabular}


dences, a possibility of new indicators creation. Supports 9 graphical styles. Allows creating, testing and optimizing trade systems.

Qualitative estimations of stock market analytical automated systems on 8 criteria are represented in table 6 . In this table global criteria weights $w_{k}^{G}$ are also adduced. In table 7 stock market analytical systems ratings are built based on the using of suggested Verbal AHP and erbal $^{+} A H P$ algorithms.

High score of Reuters Graphics Professional is explained by that only this system among considered software supports the fundamental analysis, which has high significance. Super Charts has the worst score because this system is intended mainly for training in technical analysis and has limitations in functionality.

The sequence of the alternatives coincides in both ratings. The difference in absolute values of rating indexes is explained by using the same scales in the first case - for estimation quality of stock market analytical systems on criteria, and in the second case - for estimation their relative superiorities. The given ratings characterize functionality of considered analytical systems and could be used hereinafter for the analysis of acceptability of their prices, as that was made in the works [4] for expert systems and in the book [5] for office software.

Table 6. Qualitative estimations of stock market analytical automated systems

\begin{tabular}{|c|c|c|c|c|c|c|}
\hline Criteria & $w_{k}^{G}$ & TS & $\mathrm{SC}$ & RGP & DEC & MSP \\
\hline $\begin{array}{l}\text { Fundamental } \\
\text { analysis }\end{array}$ & 0.3 & $\mathrm{ABS}, \mathrm{c}^{\mathrm{ABS}}=1$ & $\mathrm{ABS}, \mathrm{c}^{\mathrm{ABS}}=1$ & $\mathrm{AVG}, \mathrm{c}^{\mathrm{AVG}}=1$ & $\mathrm{ABS}, \mathrm{c}^{\mathrm{ABS}}=1$ & $\mathrm{ABS}, \mathrm{c}^{\mathrm{ABS}}=1$ \\
\hline $\begin{array}{l}\text { Possibility of us- } \\
\text { ing different } \\
\text { length trends }\end{array}$ & 0.15 & $\mathrm{H}, \mathrm{c}^{\mathrm{H}}=1$ & $\begin{array}{l}\mathrm{BA}, \mathrm{c}^{\mathrm{BA}}=0.6 \\
\quad \mathrm{AVG}, \mathrm{c}^{\mathrm{AVG}}=0.4\end{array}$ & $\mathrm{AVG}, \mathrm{c}^{\mathrm{AVG}}=1$ & $\mathrm{H}, \mathrm{c}^{\mathrm{H}}=1$ & $\mathrm{AA}, \mathrm{c}^{\mathrm{AA}}=1$ \\
\hline $\begin{array}{l}\text { Possibility of dif- } \\
\text { ferent graphical } \\
\text { interpretation of } \\
\text { stock price trends }\end{array}$ & 0.1 & $\mathrm{H}, \mathrm{c}^{\mathrm{H}}=1$ & $\begin{array}{l}\mathrm{BA}, \mathrm{c}^{\mathrm{BA}}=0.6 \\
\mathrm{AVG}, \mathrm{c}^{\mathrm{AVG}}=0.4\end{array}$ & $\mathrm{BA}, \mathrm{c}^{\mathrm{BA}}=1$ & $\begin{aligned} \mathrm{AVG}, \mathrm{c}^{\mathrm{AVG}}=0.3 \\
\mathrm{AA}, \mathrm{c}^{\mathrm{AA}}=0.7\end{aligned}$ & $\begin{array}{l}\text { BA, } c^{\mathrm{BA}}=0.8 \\
\text { AVG, } c^{\mathrm{AVG}}=0.2\end{array}$ \\
\hline $\begin{array}{l}\text { Possibility of } \\
\text { new indicators } \\
\text { creation }\end{array}$ & 0.1375 & $\begin{array}{l}\mathrm{ABS}, \mathrm{c}^{\mathrm{ABS}}=0.5 \\
\mathrm{~L}, \mathrm{c}^{\mathrm{L}}=0.5\end{array}$ & $\mathrm{ABS}, \mathrm{c}^{\mathrm{ABS}}=1$ & $\mathrm{H}, \mathrm{c}^{\mathrm{H}}=1$ & $\begin{array}{l}\mathrm{ABS}, \mathrm{c}^{\mathrm{ABS}}=0.5 \\
\mathrm{~L}, \mathrm{c}^{\mathrm{L}}=0.5\end{array}$ & $\mathrm{H}, \mathrm{c}^{\mathrm{H}}=1$ \\
\hline $\begin{array}{l}\text { Amount of indi- } \\
\text { cators }\end{array}$ & 0.1125 & $\begin{array}{l}\mathrm{AA}, \mathrm{c}^{\mathrm{AA}}=0.1 \\
\mathrm{H}, \mathrm{c}^{\mathrm{H}}=0.9\end{array}$ & $\begin{array}{l}\mathrm{AVG}, \mathrm{c}^{\mathrm{AVG}}=0.2 \\
\mathrm{AA}, \mathrm{c}^{\mathrm{AA}}=0.8\end{array}$ & $\begin{array}{l}\mathrm{AVG}, \mathrm{c}^{\mathrm{AVG}}=0.6 \\
\mathrm{AA}, \mathrm{c}^{\mathrm{AA}}=0.4\end{array}$ & $\begin{array}{l}\mathrm{BA}, \mathrm{c}^{\mathrm{BA}}=0.8 \\
\mathrm{AVG}, \mathrm{c}^{\mathrm{AVG}}=0.2\end{array}$ & $\begin{array}{l}\text { AA, } \mathrm{c}^{\mathrm{AA}}=0.3 \\
\mathrm{H}, \mathrm{c}^{\mathrm{H}}=0.7\end{array}$ \\
\hline $\begin{array}{l}\text { Analysis of stock } \\
\text { returns }\end{array}$ & 0.1 & $\mathrm{ABS}, \mathrm{c}^{\mathrm{ABS}}=1$ & $\mathrm{ABS}, \mathrm{c}^{\mathrm{ABS}}=1$ & $\mathrm{AA}, \mathrm{c}^{\mathrm{AA}}=1$ & $\mathrm{ABS}, \mathrm{c}^{\mathrm{ABS}}=1$ & $\mathrm{ABS}, \mathrm{c}^{\mathrm{ABS}}=1$ \\
\hline Additional tools & 0.06 & $\begin{array}{l}\mathrm{AA}, \mathrm{c}^{\mathrm{AA}}=0.6 \\
\mathrm{H}, \mathrm{c}^{\mathrm{H}}=0.4\end{array}$ & $\begin{array}{l}\mathrm{H}, \mathrm{c}^{\mathrm{H}}=0.8 \\
\mathrm{VH}, \mathrm{c}^{\mathrm{VH}}=0.2\end{array}$ & $\begin{array}{l}\mathrm{AA}, \mathrm{c}^{\mathrm{AA}}=0.1 \\
\mathrm{H}, \mathrm{c}^{\mathrm{H}}=0.9\end{array}$ & $\mathrm{H}, \mathrm{c}^{\mathrm{H}}=1$ & $\begin{array}{l}\mathrm{AA}, \mathrm{c}^{\mathrm{AA}}=0.9 \\
\mathrm{H}, \mathrm{c}^{\mathrm{H}}=0.1\end{array}$ \\
\hline $\begin{array}{l}\text { Built-in pro- } \\
\text { gramming lan- } \\
\text { guage and pro- } \\
\text { gramming editor }\end{array}$ & 0.04 & $\mathrm{H}, \mathrm{c}^{\mathrm{H}}=1$ & $\begin{array}{l}\mathrm{BA}, \mathrm{c}^{\mathrm{BA}}=0.9 \\
\quad \mathrm{AVG}, \mathrm{c}^{\mathrm{AVG}}=0.1\end{array}$ & $\mathrm{ABS}, \mathrm{c}^{\mathrm{ABS}}=1$ & $\mathrm{ABS}, \mathrm{c}^{\mathrm{ABS}}=1$ & $\mathrm{ABS}, \mathrm{c}^{\mathrm{ABS}}=1$ \\
\hline
\end{tabular}

Table 7. Ratings of stock market analytical automated systems

\begin{tabular}{clcc}
\hline \multirow{2}{*}{ Number } & $\begin{array}{c}\text { Stock market analyt- } \\
\text { ical system }\end{array}$ & with using Verbal $^{+}$AHP & Generalized score $\boldsymbol{Z}_{\boldsymbol{i}}$ \\
with using Verbal AHP
\end{tabular}

\section{Conclusion}

As a result of given research two algorithms for evaluation of stock market analytical automated systems were worked out, based on Zahedi's AHP-method modifications. The main distinctive peculiarity of these algorithms consists in using of qualitative (verbal) expert estimations in the generalized quantitative score obtaining. Verbal estimations applied for the expression of alternative relative superiority on criteria in the first algorithm (Verbal 
$A H P$ ), and for the alternatives evaluation on criteria - in the second algorithm $\left(\mathrm{Verbal}^{+} \mathrm{AHP}\right)$. Such a principle of alternatives and their superiorities evaluation is more convenient that quantitative assessment during special software estimation on qualitative criteria (for example, on quality of graphical features, programming editor, etc).

Production rules of transformation of the qualitative estimations into quantitative ones by means of the fuzzy interval scale were worked out in this research and used in AHP for the first time. Research results were applied to creation of stock market analytical software rating.

\section{References}

1. Ahrameiko, A.A., Zhelezko, B.A., Ksenevitch, D.V., Ksenevitch, S.V. Generalization of Saaty's analytic hierarchy process for using of fuzzy interval expert data. New Information Technologies (NITE-V): Proceedings of International scientific conference, Minsk, BSEU. Vol. 1 (2002) 217-222 (in Russian).

2. Logai, P. Main software for technical analysis of commodity and financial markets. "Companion", (1998) \#49 [Electronic resource]. - Mode of access: http://www.forex.ua/soft/soft_osn.shtml (in Russian).

3. Saaty, T. Scaling Method for Priorities in Hierarchical Structures. J. of Mathematical Psychology 3, Vol. 15 (1977) 234281 .

4. Zahedi, F.M. A method for quantitative evaluation of expert systems. European Journal of Operational Research 48 (1990) 136-147.

5. Zhelezko, B.A., Morozevitch, A.N. Information-analytical decision support systems. Minsk, NIU (1999) (in Russian).

6. Zhelezko, B.A., Siniavskaya, O.A., Ahrameiko, A.A., Berbasova, N.Y. Methodology of the estimation of quality of objects with complex structure under conditions of non-stochastic uncertainty. International Conference on Fuzzy Sets and Soft Computing in Economics and Finance (FSSCEF 2004): Proceedings, Saint-Petersburg. Vol. 2 (2004) 360 - 367. 